\title{
Lusisersily
}

\section{Modelling the sustainability of mass tourism in island tourist economies}

Xing, Y. (Author), \& Dangerfield, B. (Author). (2010). Modelling the sustainability of mass tourism in island tourist economies. Web publication/site https://doi.org/10.1057/jors.2010.77

Link to publication record in Ulster University Research Portal

Publication Status:

Published (in print/issue): 01/09/2010

DOI:

10.1057/jors.2010.77

Document Version

Publisher's PDF, also known as Version of record

\section{General rights}

Copyright for the publications made accessible via Ulster University's Research Portal is retained by the author(s) and / or other copyright owners and it is a condition of accessing these publications that users recognise and abide by the legal requirements associated with these rights.

\section{Take down policy}

The Research Portal is Ulster University's institutional repository that provides access to Ulster's research outputs. Every effort has been made to ensure that content in the Research Portal does not infringe any person's rights, or applicable UK laws. If you discover content in the Research Portal that you believe breaches copyright or violates any law, please contact pure-support@ulster.ac.uk. 


\title{
Modelling the sustainability of mass tourism in island tourist economies
}

\author{
$\mathrm{Y}^{\mathrm{Xing}}{ }^{1}$ and B Dangerfield ${ }^{2 *}$ \\ ${ }^{1}$ University of Ulster, Newtownabbey, UK; and ${ }^{2}$ University of Salford, Salford, UK
}

Tourism is one of the world's largest industries and is a source of jobs across national and regional economies. Assessing the economic, environmental and social impacts of tourism development has become a major activity within the tourism and sustainable development communities. The purpose of this research is to demonstrate the contribution of system dynamics for analysing policies that can not only promote sustainable tourism development, but also act as a warning signal to the industry about the potential negative consequences of uncontrolled growth of mass tourism, particularly in island tourist economies. Previous research in the tourism sector has been fragmented, when a holistic approach is needed in order to try to coerce some alignment in the views of the various stakeholders. The main research results illustrated in this paper are: a generic model of a tourism system informed by the (mainly) South European island tourist economies and a set of scenarios illustrating examples of policy analysis. The generic model and the modelling process developed in this research will have some transferability to other issues concerned with policymaking for sustainable development.

Journal of the Operational Research Society advance online publication, 15 September 2010

doi: $10.1057 /$ jors.2010.77

Keywords: system dynamics; sustainable development; tourist economy; tourism policy analysis

\section{Introduction}

As one of the world's largest industries, the tourism industry accounts for approximately $12 \%$ of world Gross National Product (GNP) with corresponding receipts of US\$747 billion (OECD, 2001; World Tourism Organisation (WTO), 2003). It follows that the tourism industry has a responsibility to show leadership in sustainability. Tourism is an extremely complex phenomenon, which cuts across many sectors such as transportation, hotels, fresh water supplies, waste management and energy. These aspects are not always considered as being part of the same sector and their roles in sustainable tourism development may be difficult to separate from their other functions. Also, there is a growing awareness of the negative impacts that tourism can have. Examples of such impacts on the environment, especially in coastal and mountain areas and in small islands, are described by Bramwell and Lane (1993). This growing concern, along with the principle of sustainable development (World Commission on Environment \& Development, 1987), has brought the tourism industry and international organisations to re-assess tourism policymaking in the light of its long-term economic, social and environmental sustainability.

\footnotetext{
${ }^{*}$ Correspondence: B Dangerfield, Centre for OR \& Applied Statistics, Salford Business School, University of Salford, Salford, M5 4WT, UK. E-mail: b.c.dangerfield@salford.ac.uk
}

The purpose of this research is to highlight the contribution that system dynamics can make in demonstrating the possibility of boom and bust in island tourist economies as well as for analysing policies that promote sustainable tourism development. As shown in Figure 1, in this paper a generic sustainable tourism model is described and a set of scenarios for policy analysis are presented. The scenarios are expected to be able to provide insightful information about the possible impacts of policies. In order to help the various stakeholders achieve a holistic view of tourism development and collaborative policymaking (Jamal and Getz, 1995; Roberts and Simpson, 1999; Hall, 2000; Wang and Fesenmaier, 2007; Yang, 2007), a microworld (or management flight simulator) has also been created. The details of the microworld are omitted here but are set out in Xing (2006).

\section{Conventional regression tourism demand models}

The equation shown below is a typical equation seen in a regression model for tourism demand.

$$
Q=\mathrm{F}(Y, T P, E R)
$$

where $Q=$ tourist arrivals; $Y=$ income; $T P=$ tour price; and $E R=$ exchange rate. 


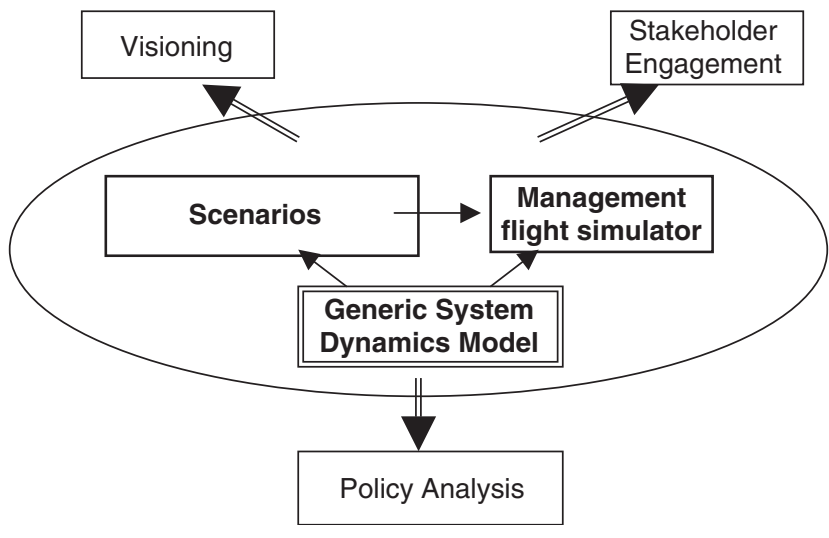

Figure 1 Research objectives in this study.

This relationship effectively analyses the changes in tourist arrivals derived from explanatory variables such as incomes, tour prices and exchange rates. It can be seen that a conventional statistical model such as this oversimplifies tourism demand to offer unreasonable correlations from a few numerical variables. Qualitative variables are overlooked, yet these soft variables can be crucial and important for policymaking. To leave out such variables and concepts is to say explicitly that they have no importance. Further, such models are usually static models that arbitrarily assume equilibrium exists.

The equation may take an explicit form such as $Q_{i t}=A P_{i t}^{\beta_{1}} Y_{i t}^{\beta_{2}} P_{s t}^{\beta_{3}} e_{i t}$, where $Q_{i t}$ is the tourism demand variable measured by tourism arrivals from country region $i$ to the tour destination at time $t ; P_{t}$ is the price of tourism in the tour destination at time $t ; P_{s t}$ is the price of tourism in the substitute destination at time $t$ and $Y_{i t}$ is the income level of the origin country or region $i$ at time $t$; and $e_{i t}$ is the residual term that is used to capture the influence of all other factors that are not included in the demand model. This last term is important as tourism demand is influenced by many economic and non-economic factors that might be excluded because of the non-availability of data. The $Q_{i t}=A P_{i t}^{\beta_{1}} Y_{i t}^{\beta_{2}} P_{s t}^{\beta_{3}} e_{i t}$ can be transformed to a linear equation in natural logarithm format, such as:

$$
\begin{aligned}
\ln Q_{i t}=\beta_{0} & +\beta_{1} \ln P_{i t}+\beta_{2} \ln Y_{i t} \\
& +\beta_{3} \ln P_{s t}+\mu_{i t},
\end{aligned}
$$

where $\beta_{0}=\ln A ; u_{i t}=\ln e_{i t}$; and $\beta_{1}, \beta_{2}, \beta_{3}$ are price, income and substitute price elasticities, respectively. Assuming equilibrium exists by letting $Q_{i t}=Q_{i t-1}$ (such as in an Autoregressive Distributed Lag Model), it is argued that this could produce the most accurate result. But the question to be raised here is: can an equilibrium be assumed? It is obviously not true in a turbulent tourism development environment. The future might not necessarily repeat history. Tourism regression models concentrate only on the tourist flow generation aspect (only one of six sectors in our model) and ignore the consequences of the volume of tourist arrivals. Without analysing the impacts of the possible actions holistically, sustainability can never be fully understood.

\section{A generic system dynamics model of an island tourist destination}

\section{Preliminary conceptualisation of the model}

According to the WTO the volume of international tourism arrivals from 1950 to 2000 grew at an average $6.8 \%$ annually worldwide, $13.2 \%$ in Asia and $6.5 \%$ in Europe. Tourism 2020 Vision (WTO, 2003) forecasts show that international tourist arrivals are expected to reach over 1.56 billion by the year 2020. This demonstrates an annual growth rate of 4.1 per cent per annum over the period 1995-2020 (Figure 2).

The driving forces for tourist flows can be classified into 'push factors' and 'pull factors' (Crompton, 1979; Pearce and Butler, 1993). However, the push and pull factors are interrelated and need to be analysed holistically. The pull and push factors taken together can be described as a 'destination consideration' (Figure 3). Clearly there is a multi-criterion issue with respect to the tourist flow to a particular destination. SWOT has been a common method for assessing a destination's Strengths, Weaknesses, Opportunities and Threats and it has been widely used among managers to assess business strategy. But it has been argued that SWOT concepts are ambiguous, qualitative and factfree (Warren, 2002). Accordingly, a SWOT analysis offers little help in answering the quantitative questions related to sustainable tourism development issues.

To analyse tourism development, we have to analyse what type of socio-economic, environmental and personal conditions generate tourist flows. Moreover, once tourist flows are generated, a range of tourism-related activities will follow. Those activities have direct or/and indirect influences on future tourist flows together with socioeconomic and environmental sustainability conditions. These conditions will in turn react on tourist flow generation and tourism-related activities. This system structure is summarised and represented in Figure 4.

\section{Basic structure of the generic tourism model}

The tourism system dynamics model (for a simplified overview see Figure 5, for details of the model see Xing, 2006) includes the following sectors: tourist flow generation, labour market, hotels, energy, water and waste, and finally transportation. The sectors contain interacting elements. In the tourist flow generation sector, 'population at tourist generation areas' (ie the source population for European tourism) and 'tourists in the tour destination' are modelled as stocks. There are three major factors affecting 


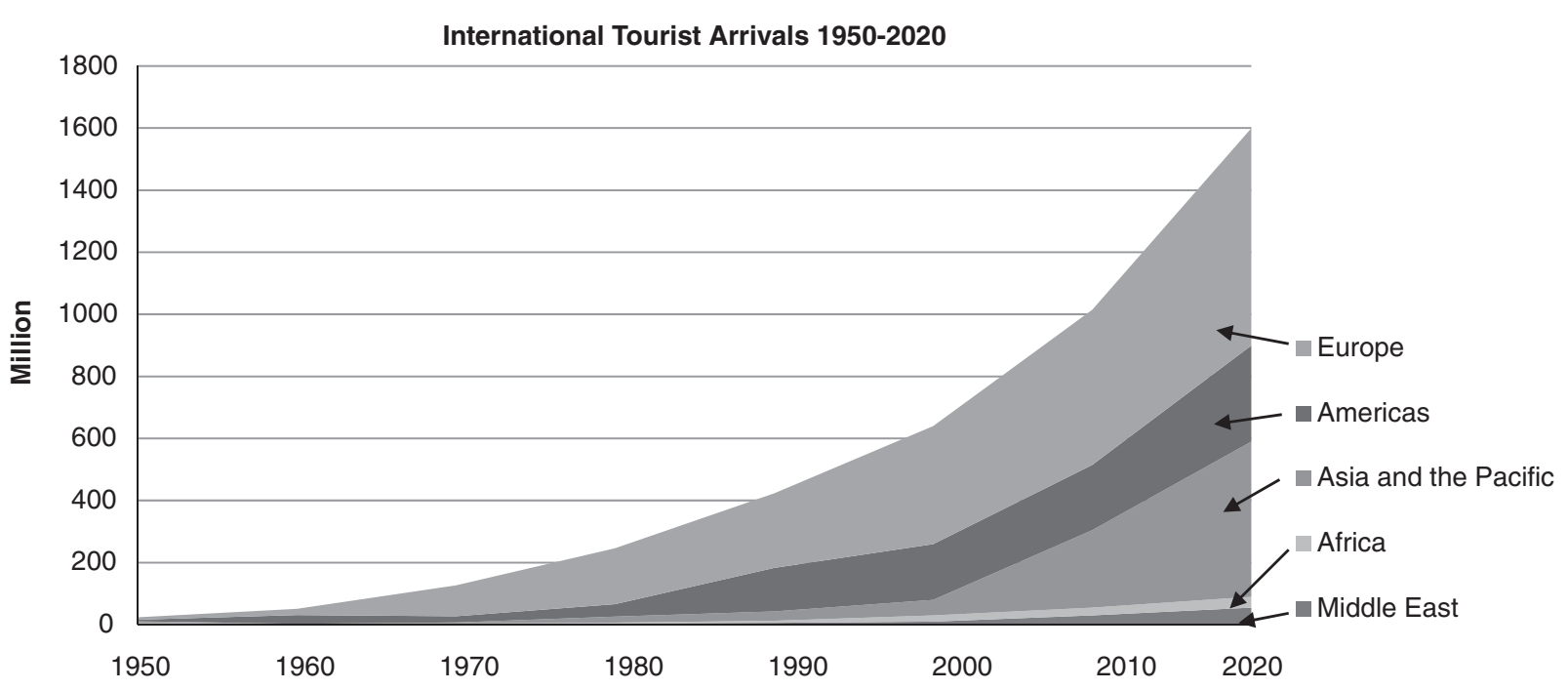

Figure 2 World tourism development (arrivals).

(Source: WTO, 2003).

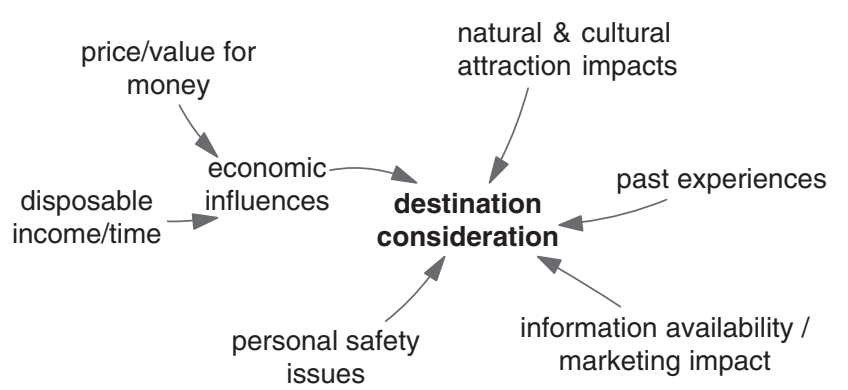

Figure 3 Destination considerations in respect of potential tourism demand.

the number of outgoing tourists: population, holiday making rate (fraction of the population making at least one trip away from the usual residence within the year) and the number of visits per person per time period. The calculation of 'tourist flow generation' (to the tour destination) reflects the effects of changes in the destination's attractiveness and capacity for accepting new tourists.

The effect of the attractiveness index (AI) on potential tourist flows to the tour destination is modelled as a nonlinear relation against the weighted AI. The model simulates generic tourism behaviour and mimics the growth of European 'sun and sand' tourism from approximately the early 1960s through to the year 2020. Therefore, using months as the basic time unit, the final time is 720. A month was selected for the basic time unit because the normal short holiday breaks taken would be small fractions of a year and this would have implied an even smaller value for the model's TIME STEP. A detailed description of the model and its equations can be found in Xing (2006).

\section{Model testing to improve users' confidence}

One of the key elements in model validation is to test whether the model fits the purpose of the modelling exercise (Forrester, 1961, p 137; Sterman, 2000, p 89). As yet, there are no islands that have experienced a boom and bust behaviour pattern, but that outcome is certainly feasible if things remain unchecked. Our paper suggests a feasibility - a possible but not assured eventuality. Two of the fundamental questions raised here in modelling the sustainability of mass tourism in island tourist economies are how to avoid a 'Tragedy of the Commons' scenario (Hardin, 1968) and a fire-fighting syndrome - the unplanned allocation of resources to fix problems discovered late in a product's development cycle (Repenning, 2001). Thus the model's utility has to be judged in respect of drawing attention to a possible eventuality given a formulation that exhibits face validity.

Testing the model is an essential step embedded within the system dynamics model construction process. The ultimate goal of model testing is to improve users' confidence in the model. Richardson and Pugh (1981) point out that 'a system dynamics model addresses a problem, not a system, and is designed to answer a reasonably well-defined set of questions'. The importance of model purpose cannot be over-emphasised: 'Fundamental to the choice of methodology is the need to define the purpose of the model, termed problem definition, and for this purpose to be agreed by all parties concerned' (Dangerfield, 2008).

On the basis of theory developed by Forrester, Senge and Sterman (Forrester and Senge, 1980; Sterman, 2000), an iterative model testing process is developed and presented as illustrated in Figure 6. 


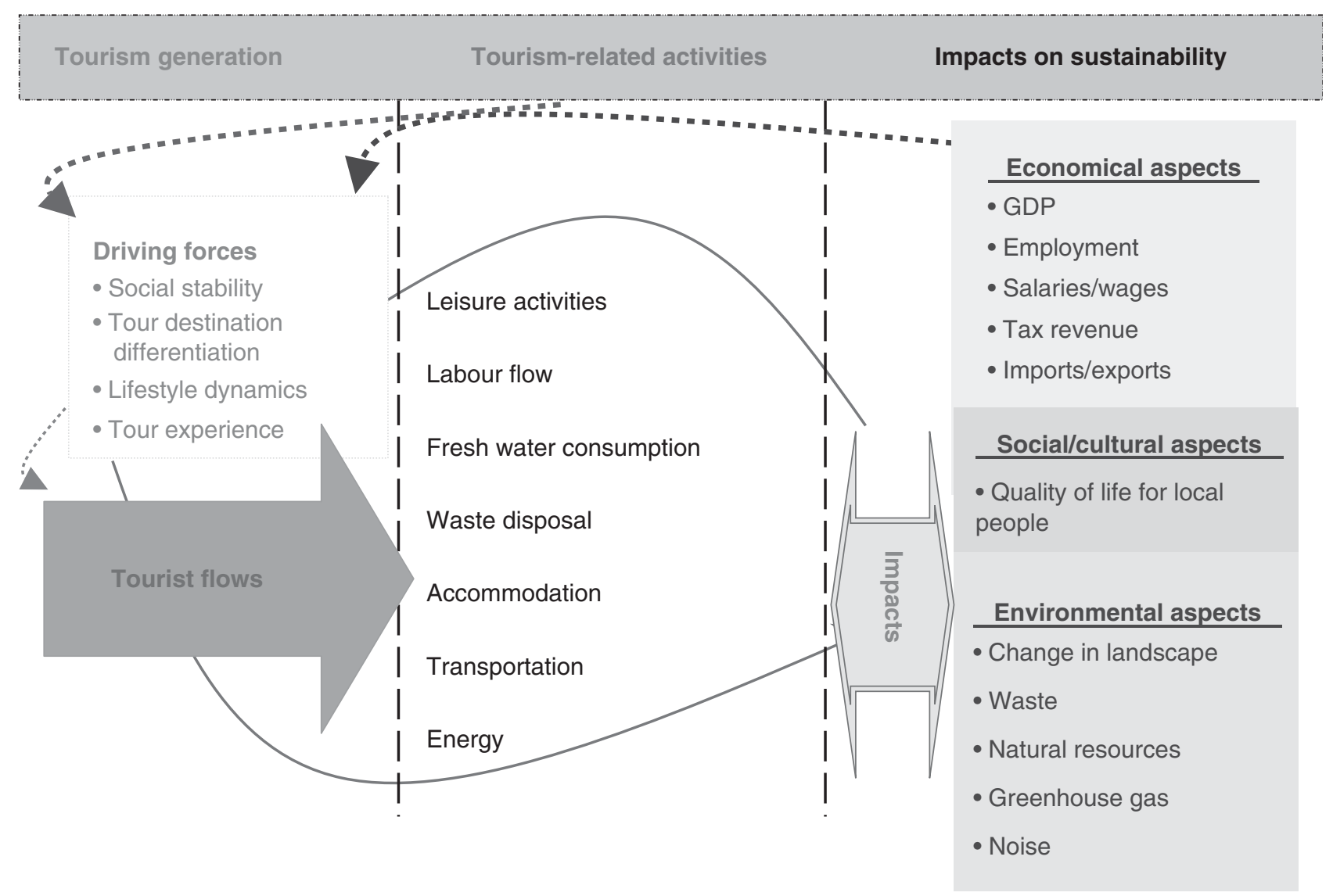

Figure 4 High-level view of tourism system structure.

Structure verification tests ask whether the model is consistent with knowledge of the real system and relevant to the purpose. For our generic model this included a halfday presentation of the model structure and assumptions to academic colleagues belonging to the (then) School of Leisure, Hospitality and Tourism at the University of Salford. Other tests conducted in this research included sensitivity analysis. This involved changing assumptions about the value of parameters in the model and examining the resulting output for consequent changes. Monte Carlo simulation (or multivariate sensitivity simulation) was utilised for this test and realised through the Vensim software that renders this procedure automatic. A 'Reality Check $^{\circledR}$, , physical consistency test and extreme condition tests were also successfully carried out in order to improve confidence in this tourism model.

To be an effective policy analysis tool, a system dynamics model should also be able to reproduce relevant aspects of past history (Homer and Keane, 1999). Our model allows an assessment of the impact on social stability of a damaging external event occurring at a tourist destination. Although this aspect of the formulation is not restricted solely to terrorist activity, it is illustrated through consideration of the terrorist bombing that occurred on October 12, 2002 in the town of Kuta on the Indonesian island of Bali, killing 202 people and injuring a further 209. Hotel occupancy rates fell to single figures within days and even in 2003 tourists were only just starting to venture back, in part as a result of massive price discounts on the island. The graph in Figure 7 shows a comparison of monthly arrival data with the simulated result. The impact of the bombing was modelled as a pulse function of delayed effects of the event (time, duration and significance). The facility to model such an eventuality is included in the tourist flow generation sector of Figure 5.

Turning to the reproduction of past history in the absence of any unanticipated external events, it has to be stressed that, since no island has yet experienced an overshoot and collapse situation in tourist numbers, any historical data (and equivalent simulation of tourist arrivals) will most likely show a continuous growth trend. The validation of the World Dynamics and Limits to Growth models by reference to past data covered only the growth phase. The projected overshoot has yet to occur and the purpose of those models was to issue a warning call: it is exactly the same here. We have created a simplified structural mechanism supporting tourist flow generation and its consequences. Then the model is articulated by tuning parameters to show plausible scenarios. Validation of a complex socio-economic system model is an on-going process. The model will evolve while 


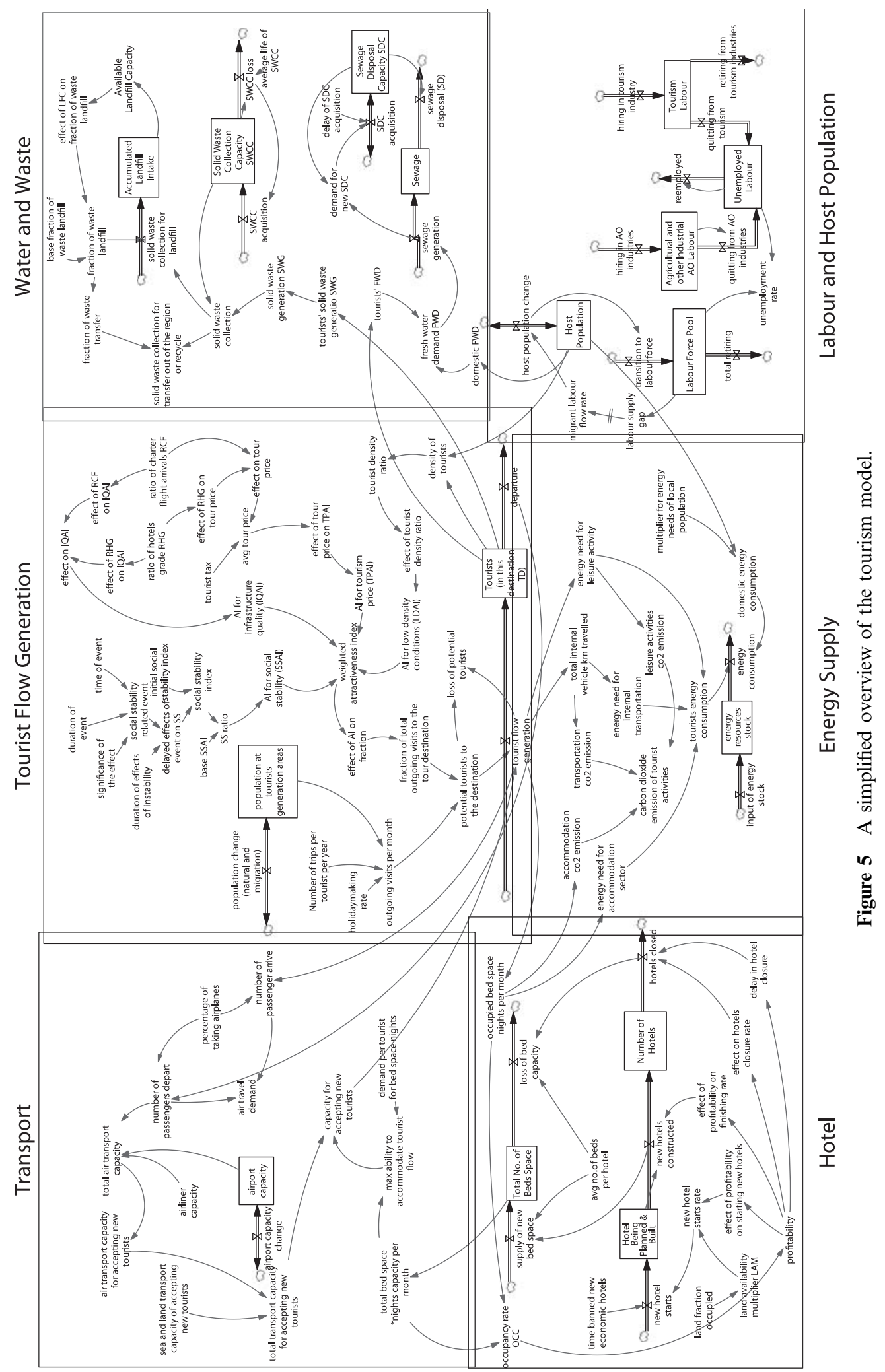




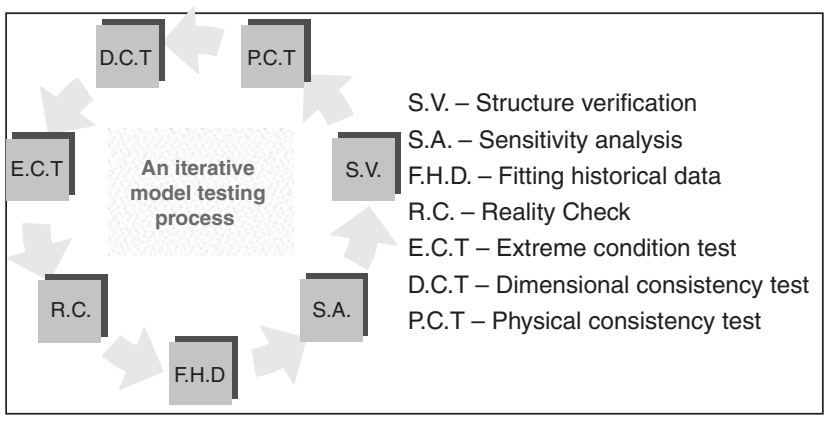

Figure 6 An iterative model testing process (adapted from Forrester and Senge, 1980).

more data and facts are established. Presently, however, the model helps us to think harder. As such, a model is very useful for analysts and policymakers to deal with what is a complex set of interacting phenomena in island tourist economies.

\section{Policy analysis based futures for mass tourism}

There is a significant amount of uncertainty, nonlinear changes and attitudinal data involved in fully understanding the forces behind tourism development. Sustainable tourism planning must be capable of addressing widely different situations (Hunter, 1997). It has long been recognised that accurate prediction is not a feasible goal. However, it is possible to formulate scenarios that can shed light on, and offer insights about, possible future developments and thereby improve organisational learning (Van der Heijden, 1996; Parry and Carter, 1998; Ringland, 1998). Scenario planning can help with a higher level of strategic thinking that integrates uncertainty-based futures thinking, a process that is necessary for sustainable tourism policy analysis.

A few attempts have been made to apply scenario planning concepts in a tourism context. For example, the Singapore Tourism Board examined a methodological process and the marketing implications of a series of events using a Delphi approach (Yong and Keng, 1989). Weaver classified and analysed four tourism destination development scenarios (Weaver, 1998). Eden and Ackermann used scenario planning techniques in strategy building for Scottish Natural Heritage (Eden and Ackermann, 1998). The WTO has used scenario planning techniques when dealing with contingency planning (WTO, 2004). However, the more widespread use of scenario planning in tourism has not been evident (Yeoman and McMahon-Beattie, 2005) and consequently there have been no significant advances in tourism development research and practice. It is argued that the fundamental problem is that written scenarios without support of formal modelling may not be adequate enough to portray the dynamic nature of the

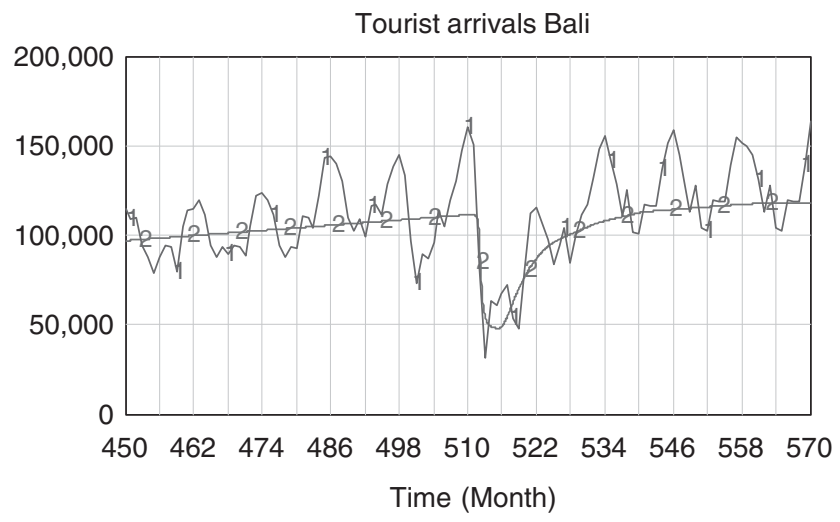

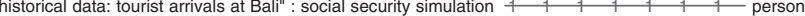
"Total Tourists (in this destination TD)" : social security simulation $\begin{array}{lllllllllll}2 & 2 & 2 & 2 & 2 & 2 & 2 & \text { person }\end{array}$

Figure 7 Comparison of simulation result with actual data. (N.B. The time axis is cropped and covers the period from 1997 to 2007.)

change, nor provide managers with a vivid enough picture of the future environment (Georgantzas and Acar, 1995; Winch, 1999; Forrester, 2003; Randers, 2005). Compared to conventional scenario analysis approaches system dynamics modelling offers the ability to visualise a dynamic portrayal of possible future developments (Georgantzas, 2003), and it employs the twin tools of diagramming techniques in a qualitative manner and quantitative modelling techniques to challenge the current knowledge base (Dangerfield, 1999; Dangerfield and Roberts, 2000).

Sometimes it is argued that the tourism industry needs constant growth and that maximal amounts of promotion are required to sustain profits and hence jobs. In the current policy context for tourism this may be more aligned with environmental sensitivities than it was 20 years ago and it is also tempered by an increasing mantle of environmental legislation. However, the underlying theme is still that of growth (Buhalis, 2000; Bramwell, 2003; Sharpley, 2004). In this section, a range of price-adjusting policies are examined. It includes changing charter flights, a potential tourist tax and policies for promoting luxury tourism by restricting new budget hotel building.

\section{Changing charter flight arrivals}

One of the most aggressive promotion strategies adapted by island tourism authorities in Southern Europe in the past several decades is to support charter flights by subsidising the tour operators for each tourist they send to the islands. An increase in the fraction of charter flight arrivals will certainly encourage further growth of mass tourism. Analyses of the possible impacts are vital for devising appropriate policies for controlling tourism growth and preventing the tourism carrying capacity of an island to be exceeded. Three scenarios are created based on a different fraction of charter flight arrivals, which have 


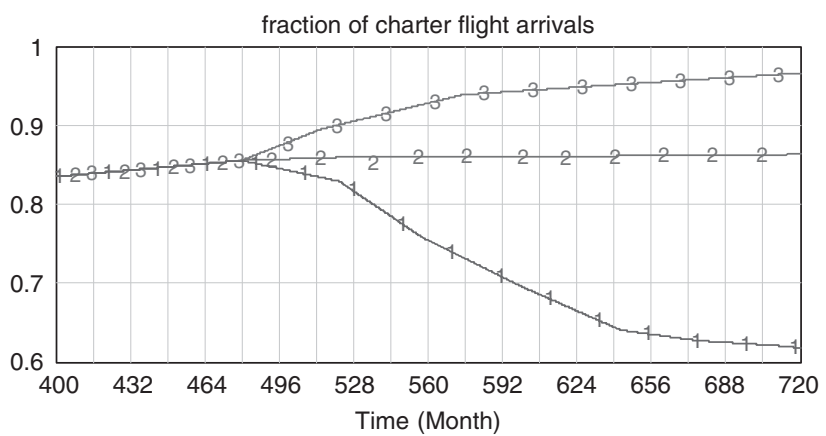

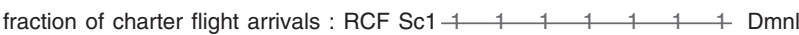
fraction of charter flight arrivals : RCF Sc2 $\begin{array}{lllllllllllllll}2 & 2 & 2 & 2 & 2 & 2 & 2 & \text { Dmnl }\end{array}$ fraction of charter flight arrivals : RCF Sc3 \begin{tabular}{lllllll}
3 & 3 & 3 & 3 & 3 & 3 & - \\
\hline
\end{tabular}

Figure 8 Three scenarios for the fraction of charter flight arrivals $(\mathrm{RCF}=$ Ratio of Charter Flights; Dmnl = dimensionless).

been driven by hypothetical policies for these arrivals and assumed to be imposed in month 480 (Figure 8). Scenario 'RCF Sc1' exhibits a lowered fraction of charter flight arrivals, scenario 'RCF Sc2' is a business as usual scenario and scenario 'RCF Sc3' has the highest fraction of charter flight arrivals.

A higher fraction of charter flight arrivals is usually associated with a higher fraction of package holidays and cheaper accommodation. The simulated result on the total tour expenditure of the three scenarios can be seen in Figure 9. The scenario 'RCF Scl' has a lower fraction of charter flight arrivals and thus a higher fraction of scheduled flight arrivals, which indicates a higher expenditure in terms of transportation and associated accommodation expenditure. This scenario has a higher average tour price than the base scenario and, consequently, reduced tourist arrivals. However, it generates the largest tourist expenditure by compensating for reduced tourist arrivals with a greater margin gained from the higher tour price.

Large tour operators in Europe usually have had a strong influence on the way tourism has evolved, particularly because there are a relatively small number of tour operators at the lower and lower-middle end of the market. Large operators are committed to filling charter flights. This encourages a short-term perspective and allows that market segment to be dominated by customers who holiday abroad because it is cheap, rather than from a desire to experience and appreciate foreign cultures and environments.

\section{A tourist tax?}

A tourist tax was levied recently in Spain with the intention of mitigating the negative effects from the rapid growth of mass tourism in some of their islands. This had considerable effects on the hotel industry. In April 2001, the Balearic Islands regional government approved Europe's first tourist tax, in spite of opposition from the national government in Madrid and tour operators in the UK and Germany. From early 2002, visitors to Majorca, Ibiza, Minorca and Formentera had to pay an average of 1 euro a day each on checkout if they had been staying in a hotel, hostel, villa or apartment. The intended use of the tax was to fund environmental projects on the Balearic islands (Tremlett, 2002).

The tax was unpopular with holidaymakers (particularly those on a budget). It was unpopular with hoteliers who had to collect the tax. It was unpopular with tour operators because they feared for a decline in tourist numbers. Many hotels and villa management companies did not collect the tax and absorbed it into expenses, while some hotels disbursed vouchers that clients could spend on the premises - described by some tourists as the 'Lemonade Tax' (The Independent, 2003). The tax was collected for the intended environmental purposes, though the impact was not large.

The growing trend of mass tourism in those islands was not deterred by the tourist tax. But hoteliers and tourist firms claimed that the tax on visitors was harming tourism and refused to collect it (The Independent, 2003). From October 2003, authorities in the Balearic Islands scrapped the tourist tax after local companies rebelled against it.

It is obvious that an integrated approach is required for tourist tax policy analysis. Opposed to the tourist tax policy failure in the Balearics, there is a successful story in Asia. The government of Bhutan in the Himalayas has imposed a tourist tax of 200 US dollars per day on tourists going into Bhutan (Tourist Authority of Bhutan, 2005). This tariff usually covers guides, food and accommodation. This is a radical effort not only to try and reduce tourist numbers but also to increase the revenue coming from tourism - a very successful strategy (Bhattarai et al, 2005). The Bhutan Tourism Authority is emphasising the development of products that are unique to Bhutan. The living culture of Bhutan and eco-tourism are said to be the two main attractions at the moment.

The scope of our model (Figure 5), while encompassing environmental issues such as water, waste and energy, does not extend to environmental protection, so the impact of any tourist tax is restricted to its effect on visitor numbers. We have analysed the impact on tourist arrivals resulting from the imposition of various rates of tourist tax. The figures in Table 1 present four different scenarios (from zero tourist tax to a high tax). Their effects on the tour price AI, which has an arbitrary scale from 0 to 100, and tourist arrivals follow in Figures 10 and 11, respectively.

An arbitrary date of the 10th year (month 120) is the assumed date for the introduction of the tax. From the above figures it can be seen that tourist arrivals are very sensitive to the rate of the tourist tax when the tax is above the medium level (400 euro per person per month). However, although a case might be made for a modest tax imposition, in complex social and economic 
Table 1 Four tourist taxation scenarios

\begin{tabular}{lrr}
\hline Tax Scenarios & Volume of tourist tax (euro/month/person) & Time of tax levy (month) \\
\hline taxBase (zero tourist tax scenario) & 0 & None \\
taxSc 1 (Low tax scenario, eg Balearics tourist tax) & 40 & 120 th \\
taxSc 2 (medium tax scenario) & 400 & 120 th \\
taxSc 3 (high tax scenario, eg Bhutan tourist tax) & 4000 & 120 th \\
\hline
\end{tabular}

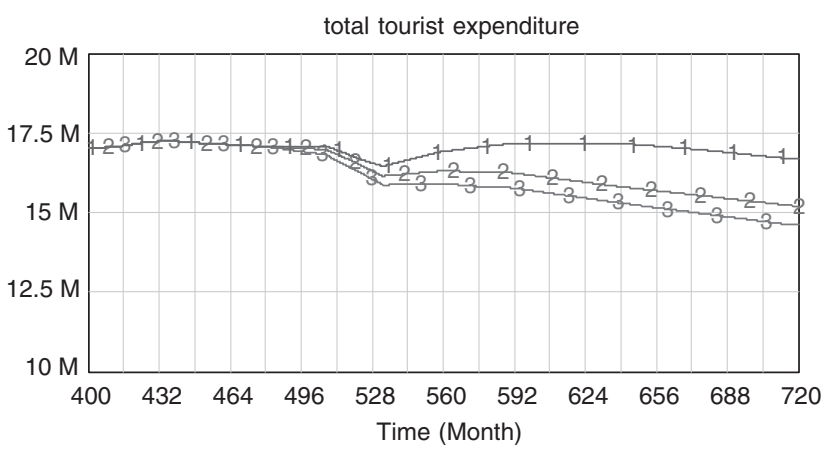

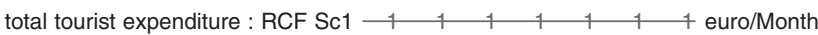
total tourist expenditure : RCF Sc2 $\begin{array}{llllllll}2 & 2 & 2 & 2 & 2 & 2\end{array}$ euro/Month total tourist expenditure : RCF Sc3 $\begin{array}{lllllll}3 & 3 & 3 & 3 & 3 & 3 & 3\end{array}$ euro/Month

Figure 9 Impact of charter flight arrival scenarios on total tourist expenditure.

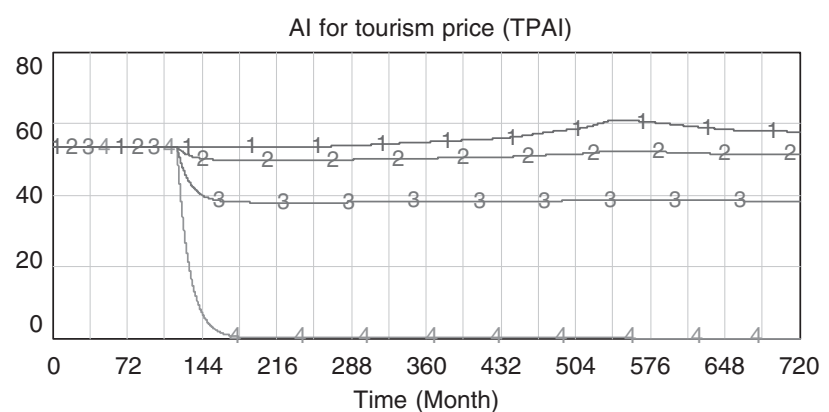

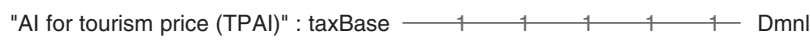
"Al for tourism price (TPAI)" : $\begin{array}{lllllllll}\operatorname{taxSc} 1 & 2 & 2 & 2 & 2 & 2 & 2 & \text { Dmnl }\end{array}$ "Al for tourism price (TPAI)" : $\operatorname{taxSc2} \begin{array}{lllllll}3 & 3 & 3 & 3 & 3 & 3 & 3 m n l\end{array}$

"Al for tourism price (TPAI)" : $\operatorname{taxSc3} \begin{array}{llllllll} & 4 & 4 & 4 & 4 & 4 & \text { Dmnl }\end{array}$

Figure 10 Impact of tourist taxation on Tour Price Attractiveness Index (TPAI).

environments, such as island tourist economies, multiple factors need to be considered and dealt with, such as stakeholders' engagement or decision-making based upon demographics. This will involve, inter alia, hoteliers, tour operators and the local workforce. In order to avoid conflicts between hoteliers and policymakers over a tourism tax policy, as occurred in the Balearic Islands, mutual consensus between different stakeholders has to be achieved.

For modest tax scenarios the effect on arrivals is temporary and does not ultimately prevent the inexorable

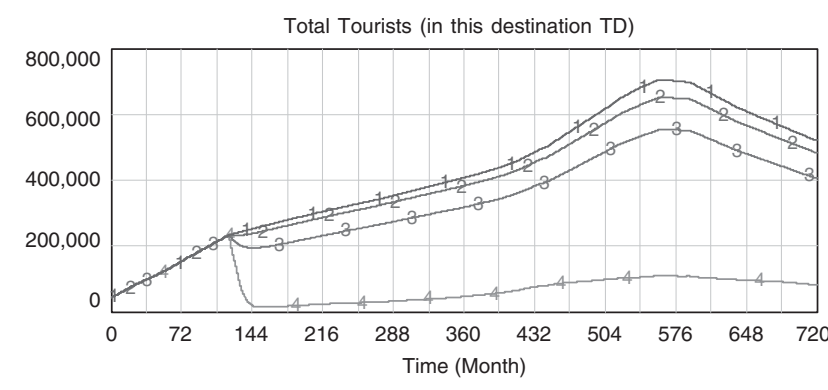

"Total Tourists (in this destination TD)" : taxBase $14 \begin{array}{llllll}1 & 1 & 1 & 1 & 1 & 1\end{array}$ "Total Tourists (in this destination TD)" : taxSc1 $\begin{array}{llllllllll}2 & 2 & 2 & 2 & 2 & 2 & 2\end{array}$ person "Total Tourists (in this destination TD)" : $\operatorname{taxSc2} \begin{array}{llllllll}3 & 3 & 3 & 3 & 3 & 3 & 3 & 3\end{array}$

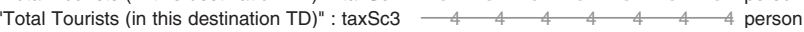

Figure 11 Impact of tourist taxation on arrivals at a tour destination.

rise in the numbers of tourists. Growth hits a peak only when other limits manifest themselves around 35 years later.

\section{Restricting the construction of new budget hotels}

Upon realising the possible negative impacts of mass tourism, some South European islands are aiming more at the upper market segments by subsidising new luxury hotel building and restricting the construction of budget hotels. But the effectiveness and possible impact of such a policy on tourism development has barely been studied. In an attempt to evaluate this policy a scenario: 'hotel banned scl'- in which we assume new budget (economic) hotel building is completely banned from the 498th month (equivalent to end-June 2001) - is compared with the base case 'hotel base'.

In the 'hotel banned scl' scenario, the numbers of new hotels constructed (Figure 12) takes time to change because of work already in the pipeline, but clearly luxury hotel building increases due to the increased demand for accommodation. Of particular interest is Figure 13, which shows that it takes a considerable time to change the hotel mix, and hence the economic status of the clientele. For this evaluation, while the absolute numbers can be questioned (around three new hotels per annum), the emphasis is on a comparison between the two policies. In this respect the policy precept is that it takes too long for the effects (of the draconian policy of termination of the construction of budget hotels) to manifest themselves. 


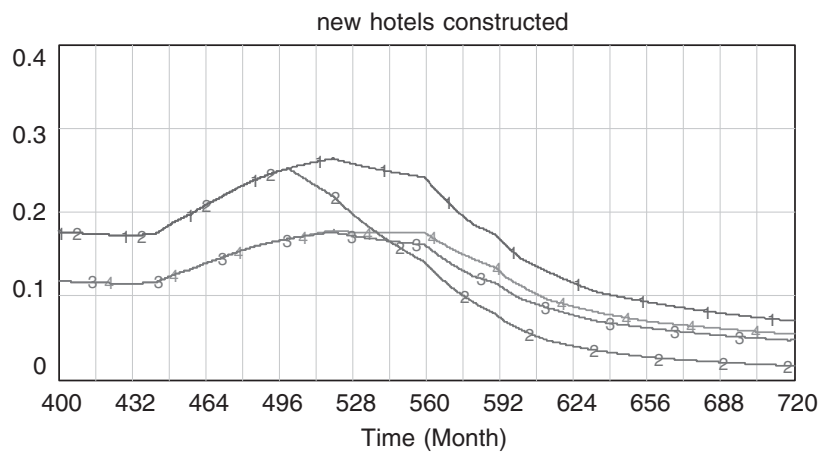

new hotels constructed[economic] : hotel base $14,1,1,1,1,1+1$, hotel/Month

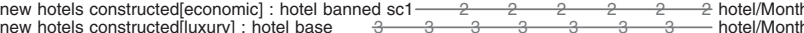

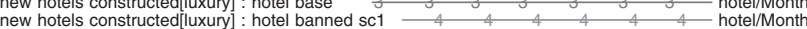

Figure 12 Completed rates of construction of different hotel types after the policy change in month 498 (half way through 2001).

Growth limits are likely to be reached anyway and this will affect all new hotel construction.

\section{Discussion}

It has been observed that the insistence that 'cheap' is beautiful has been an illness in the package tourism industry. For too long this industry has suffered from a self-perpetuating cycle of sending more tourists greater distances for less profit. Under these circumstances, companies are more concerned about staying in business than protecting their hosts' livelihood from unsustainable damage.

This vicious circle is illustrated in Figure 14, which depicts a positive feedback loop in which more budgetprice holidays are impacting on the tour companies' profits and which in turn exacerbates the pressure. Companies could become insolvent by operating on a too-low price base and then keep going from year to year by simply changing the name of the business. This is in the interests neither of the business nor of the customer, yet it is possible because of free market entry. Some tour operators claim that this problem hinders collective action by operators to increase margins. However, any collective agreements to increase stability or raise margins would be opposed by the Office of Fair Trading in the UK.

Nonetheless, the direction of the vicious cycle must be reversed. Researchers have argued that practices for sustainable tourism offer techniques that can reverse the trend by offering a variable holiday product. An increase in the range and quality of holidays should be associated with greater margins and the chance to compete on more sustainable resources than just price. Evidence suggests that this could be a long-term opportunity for operators to add value to the service they provide. A genuinely sustainable approach to tourism should have benefits for all. For those involved in the industry it means long-term

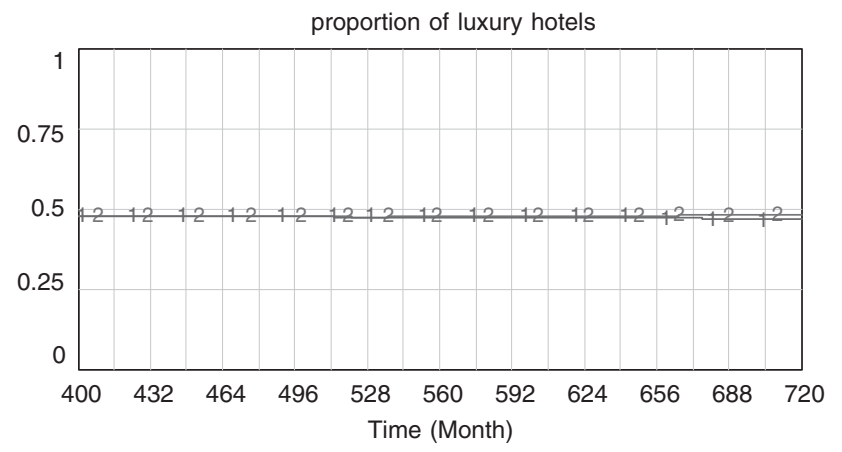

proportion of luxury hotels : hotel base $\begin{array}{lllllll}1 & 1 & 1 & 1 & 1 & 1 & 1\end{array}$ proportion of luxury hotels : hotel banned sc1 $\begin{array}{lllllll}2 & 2 & 2 & 2 & 2 & 2 & 2\end{array}$

Figure 13 Proportion of luxury hotels in the accommodation mix.

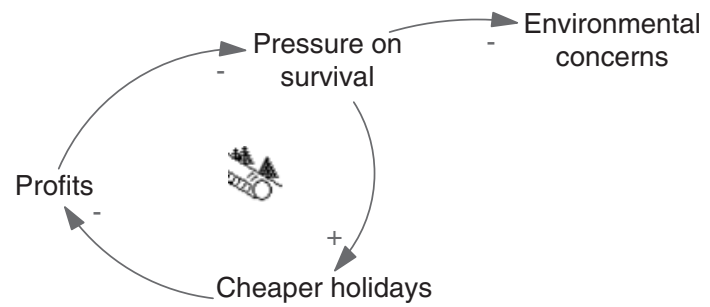

Figure 14 Effects of pressure on survival in a cheap holiday market.

profitability and a need to avoid a potential boom-andbust. As we have shown, there are always limits to growth. If some island tourist destinations become over-dependent on tourism-even over many decades - they may eventually experience sharply contracting visitor numbers (and profits) thereby destroying their original attractions. An example is the boom and bust tourism development in mainland Southern Spain during the 1980s (Forsyth, 1996).

Sustainable tourism development, compared to the practice of price-cutting, has a number of benefits for all the stakeholders, such as:

- Adding value to holiday packages by offering more to tourists than the standard sun, sea and sand.

- Cutting costs by recycling waste products and reducing unnecessary fuel consumption.

- Active involvement with local authorities and communities by liaising with industry suppliers to provide products that support local industries and avoid environmental damage.

- Sustainability is not peripheral to the tourism industry, but is in fact central to breaking the downward spiral of sending more and more tourists greater distances for less profit.

However, enforcing sustainable tourism policies is extremely difficult. Policymakers and destination managers need to formulate an integrated public-private partnership and 
develop opportunities for understanding by all stakeholders in order that they might realise the importance of maintaining a fairly standardised pricing structure and policy. Furthermore, sustainable tourism does not come from imposing polices alone, or from simple checklists or isolated initiatives. Rather, it depends on an insightful understanding of exactly how the tourism system functions and interacts through time with the other industries in which it operates. Put simply: there is a need for a systemic approach to tourism policy with the purpose of surfacing the often conflicting actions of the various system stakeholders who are driven by their own missions and goals. If policy remains as un-coordinated as at present, then the likelihood is of a 'Tragedy of the Commons' scenario (Hardin, 1968) and the possible demise of one or more island tourist economies.

\section{Conclusions}

Sustainable tourism development problems are replete with nonlinearities, feedback and considerable complexity. However, it is impossible to prove that any simulator that aims to tackle this complexity is a correct or 'true' model of the real system at the time of modelling. As yet, no European island has experienced boom and bust, but that behaviour is certainly feasible if the tourist destinations are not managed wisely. Tourism dynamics, as shown in this paper, provide a warning sign that such behaviour is feasible. Sustainable development models cannot be validated by any one test such as their ability to fit historical data. A good fit to data during the growth phase says nothing about the timing and magnitude of any incipient peak and eventual decline in tourist arrivals. Model testing should be regarded as the process of bringing the user's confidence to an acceptable level such that any policy inference about the system, derived from running the model, is one upon which a high degree of reliance can be placed.

Sustainable development problems are system problems: the solutions must involve looking at the impact of changes on as much of the system as possible. Partial solutions are likely to be ineffective and may even make things worse. Changes throughout the system must be co-ordinated. It is not sufficient for individual units to change without understanding the impact such changes will make on other parts of the system. In order to formulate sustainable tourism development policies, the following three steps have to be taken:

1. To conceptualise a whole-system picture that captures the most important variables and interrelationships.

2. To carry out a detailed analysis based on integration of hard and soft data and methodologies.

3. To improve stakeholder engagement and participation in policy analysis and policymaking.
The artefacts developed in this research (the generic tourism system dynamics model, policy scenarios and the microworld - see Xing, 2006) provide a powerful means to enhance the accomplishment of the three tasks identified. The tourism system dynamics model described in this paper identifies a number of essential feedback structures that have profound effects on sustainable tourism development. Rather than providing a forecast of a predetermined future, the model develops a means of testing alternative scenarios for policy analysis and stakeholder collaboration. This research focuses on the evolution of a holistic framework together with a generic model for achieving the aspiration of the sustainable development of (particularly island) tourism.

From a methodological perspective this research shows that system dynamics provides a way of visualising tourism as a network of integrated systems, including demographic, cultural, economic and energy, while rigorously inferring their performance through quantification and the use of computer simulation. System dynamics modelling can serve as a vehicle for integrating multiple data resources and multiple methods from marketing, finance, operations and other functional spheres of tourism. Explicit mapping and analysis of feedback in a system dynamics model reveals an intuitive grasp of dynamics and enhances the quality of debate while eliciting new knowledge. It keeps us thinking hard about how to design the future.

Future work can be drawn out from the analysis presented in this paper in several ways. First, the generic model can be parameterized to represent the dynamics of tourism development for a particular island more precisely. Second, the generic model and modelling process presented in this paper can be applied to sustainable development analysis for other industries. Third, the analysis of sustainable tourism development can be integrated with other long-term sustainable development modes, such as sustainable urban development or sustainable regional development.

Acknowledgements - Thanks are due to the University of Salford, UK for funding this research.

\section{References}

Bhattarai K, Conway D and Shrestha N (2005). Tourism, terrorism and turmoil in Nepal. Ann Tourism Res 32: 669-688.

Bramwell B (ed). (2003). Coastal Mass Tourism: Diversification and Sustainable Development in Southern Europe. Channel View: Clevedon.

Bramwell B and Lane B (1993). Sustainable tourism: An evolving global approach. J Sustainable Tourism 1: 1-5.

Buhalis D (2000). Marketing the competitive destination of the future. Tourism Mngt 21: 97-116.

Crompton JL (1979). Motivations for pleasure vacation. Ann Tourism Res 6: 408-428.

Dangerfield B (1999). System dynamics applications to European health care issues. $J$ Opl Res Soc 50: 343-353. 
Dangerfield B (2008). System dynamics advances strategic economic transition planning in a developing nation. In: QudratUllah H, Spector M and Davidsen P (eds). Complex DecisionMaking: Theory \& Practice. Springer: New York, pp 185-209.

Dangerfield B and Roberts C (2000). A strategic evaluation of capacity retirements in the steel industry. $J$ Opl Res Soc 51: 53-60.

Eden C and Ackermann F (1998). Making Strategy: The Journey of Strategic Management. Sage: London.

Forrester JW (1961). Industrial Dynamics. MIT Press: Cambridge, MA, now available from Pegasus Communications, Waltham, MA.

Forrester JW (2003). Economic theory for the new millennium. In: Eberlein R (ed). Proceedings of the International System Dynamics Conference, System Dynamics Society (CD-ROM): New York.

Forrester JW and Senge P (1980). Tests for building confidence in system dynamics models. In: Augusto AL, Forrester JW and Lyneis JM (eds). TIMS Studies in the Management Sciences. Vol. 14. North-Holland: Oxford, pp 209-228.

Forsyth T (1996). Sustainable Tourism: Moving from Theory to Practice Prepared by Tourism Concern. World Wide Fund for Nature (UK), Godalming: England.

Georgantzas N (2003). Tourism dynamics: Cyprus' hotel value chain and profitability. Syst Dynam Rev 19: 175-212.

Georgantzas N and Acar W (1995). Scenario-Driven Planning: Learning to Manage Strategic Uncertainty. Quorum Books: Westport, CT.

Hall M (2000). Tourism Planning: Policies, Processes and Relationships. Pearson Education Limited: Essex, UK.

Hardin G (1968). The tragedy of the commons. Science 162: 1243-1248.

Homer JB and Keane TE (1999). Evaluating strategies to improve railroad performance- $A$ system dynamics approach. In: Farrington PA, Nembhard HB, Sturrock DT and Evans GW (eds). Winter Simulation Conference. Proceedings IEEE: Arizona, pp 1186-1193.

Hunter C (1997). Sustainable tourism as an adaptive paradigm. Ann Tourism Res 24: 850-867.

Independent (2003). Balearic isles scrap eco-tax on tourists. 30 October, London, p15.

Jamal TB and Getz D (1995). Collaboration theory and community tourism planning. Ann Tourism Res 22: 186-204.

OECD (2001). Tourism. Vol. 2003. OECD, http://www.oecd.org/ department $/ 0,2688$,en_2649_34389_1_1_1_1_1,00.html, accessed January 2004.

Parry M and Carter T (1998). Climate Impact and Adaptation Assessment. Earthscan Publications Ltd: London, UK.

Pearce D and Butler R (1993). Tourism Research-Critiques and Challenges. Routledge: London.

Randers J (2005). 30 years beyond the limits: An interview with Jørgen Randers: Co-author of 'The Limits to Growth'. In: 'News and Analysis for Futures Studies \& Scenario Planning'. Plausible Futures Newsletter, http://www.plausiblefutures.com/ 2007/04/30-years-beyond-the-limits-an-interview-with-jørgenranders/ accessed September 2010.

Repenning N (2001). Understanding fire fighting in new product development. J Prod Innovat Mngt 18(5): 285-300.
Richardson GP and Pugh AL (1981). Introduction to System Dynamics Modelling with DYNAMO. MIT Press: Cambridge, MA, now available from Pegasus Communications, Waltham, MA.

Ringland G (1998). Scenario Planning-Managing for the Future. Wiley: Chichester, UK.

Roberts L and Simpson F (1999). Developing partnership approaches to tourism in Central and Eastern Europe. $J$ Sustainable Tourism 7: 314-330.

Sharpley R (2004). Tourism, modernisation and development on the Island of Cyprus: Challenges and policy responses. In: Bramwell B (ed). Coastal Mass Tourism-Diversification and Sustainable Development in Southern Europe. Channel View Publications: Clevedon, pp 321-340.

Sterman J (2000). Business Dynamics: Systems Thinking and Modeling for a Complex World. Irwin/McGraw-Hill: New York.

Tourist Authority of Bhutan (2005). Official tourist information. Tourism Authority of Bhutan, http://www.tourism.gov.bt/ accessed December 2005.

Tremlett G (2002). Green tax helps islands clean up. The Guardian, May, London, p 11.

Van der Heijden K (1996). Scenarios: The Art of Strategic Conversation. Wiley: Chichester.

Wang Y and Fesenmaier DR (2007). Collaborative destination marketing: A case study of Elkhart county, Indiana. Tourism Mngt 28: 863-875.

Warren K (2002). Competitive Strategy Dynamics. John Wiley \& Sons: Chichester.

Weaver DB (1998). Introduction to ecotourism. In: Weaver DB (ed). Ecotourism in the Less Developed World. CAB: Oxon, pp 1-33.

Winch G (1999). Dynamic visioning for dynamic environments. J Opl Res Soc 50: 354-361.

World Commission on Environment and Development (1987). Our Common Future. Oxford University Press: Oxford, UK.

WTO (2003). Long-term prospects: Tourism 2020 vision. World Tourism Organisation, http://www.world-tourism.org/facts/eng/ vision.htm, accessed January 2006.

WTO (2004). Indicators of Sustainable Development for Tourism Destinations: a Guidebook. World Tourism Organization: Madrid.

Xing Y (2006). Exploring the sustainability of mass tourism in island tourist economies: a system dynamics approach. $\mathrm{PhD}$ thesis, University of Salford, Salford, UK.

Yang J-T (2007). Knowledge sharing: Investigating appropriate leadership roles and collaborative culture. Tourism Mngt 28: 530-543.

Yeoman I and McMahon-Beattie U (2005). Developing a scenario planning process using a blank piece of paper. Tourism Hospitality Res 5: 273-285.

Yong Y and Keng K (1989). A Delphi forecast for the Singapore tourism industry: Future scenario and marketing implications. Eur J Marketing 23: 3546.

Received September 2007; accepted January 2010 after one revision 